\title{
Na España de Franco dos anos corenta, lemos a poesía prebélica de Antonio Machado mercé ó xesto valente do falanxista Dionisio Ridruejo: breve achegamento
}

\author{
In Franco's Spain of the 1940's, it was possible for us to read \\ Antonio Machado's prebelic poetry thanks to the valiant \\ gesture of the phalangist Dionisio Ridruejo: a brief approach
}

\author{
Xesús Alonso Montero \\ Doutor Honoris Causa da UNED
}

\begin{abstract}
Para Manuel Rodríguez Alonso, que foi sobriño meu, amigo leal, camarada en moitas inquedanzas, rigoroso comentador de textos literarios, gran lector de don Antonio Machado e home de ben (como o propio don Antonio).
\end{abstract}

Para ti, Manolo, estas breves páxinas escritas nun tempo difícil.

Cómpre partir dun feito moi sinxelo: nos primeiros anos da Posguerra, homenaxear a don Antonio Machado máis ou menos publicamente era entendido por todos, polos vencedores da Guerra e polos vencidos, como un acto de disconformidade co Réxime. Para os que tiñan un pouco de información, dentro e fóra do Poder, Machado era unha biografía republicana simbólica: o cidadán que defendeu, no trienio bélico, a causa da República do Frente Popular, e tamén o combatente - o combatente literario- que cruzou a fronteira francesa con centos de miles de soldados e civís perseguidos con saña polo Exército vencedor.

Había, na España dos primeiros anos da Posguerra, miles e miles de persoas afectas ó Réxime, que, sen coñeceren os textos que escribira Machado contra o fascismo, en xeral, e contra o franquismo, en particular, estaban convencidas de que aquel cidadán e escritor, polo feito de actuar durante o trienio bélico na «zona roxa», era, para os desafectos, un símbolo. Como Antonio Machado era, antes de 1936, un escritor moi recoñecido dentro e fóra de España, a súa auctoritas literaria non tardou en enriquecer a súa condición cívica, axiña un icono para moitos. Nas publicacións mexicanas dos españois dese período abundan os panexíricos, todos coincidentes en salientaren a lealdade de don Antonio á causa da República en tempos tan duros e a dignidade con que viviu o seu grave e breve exilio. 
É certo, tamén, que nos primeiros anos do franquismo, moitos, afectos ou non ó Caudillo, nunca leran en España determinados textos escritos, en verso ou en prosa, por don Antonio no trienio bélico. Hai que supoñer que só un número moi exiguo de persoas coñecía a Obra completa do escritor publicada en México na editorial Séneca, e que, prologada por José Bergamín e promocionada polo entusiasmo dos exiliados, non tardaría en chegar a non poucos lectores en certos países hispanoamericanos. É nesas Completas onde figuran textos inimaxinables na España de Franco: «El crimen fue en Granada», «A Líster, Jefe de los ejércitos del Ebro», «Miaja», «A Méjico», «A otro Conde D. Julián», «Discurso a las Juventudes Socialistas Unificadas», «Carta a David Vigodky», «Sobre la Rusia actual», «El V Regimiento del 19 de julio», «Prólogo» (a Los españoles en la guerra, de Manuel Azaña).

Ós entusiastas e agradecidos ó Réxime, ignorantes, na súa inmensa maioría, destes textos e doutros semellantes, abondáballes con saber que aquel escritor, certamente con prestixio xa antes de 1936, fora leal, radicalmente leal, á causa da República, para eles a Antiespaña. Antonio Machado non era «dos nosos», era «dos outros», dos que nin sequera tiñan dereito a chamárense españois. Eran da España nefanda, tan nefandos como os españois do Século de Ouro que tiñan sangue xudeu, que non eran cristiáns vellos. No Retablo de las maravillas de Cervantes uns personaxes moi oficialescos segregábanos, en latín e en romance, nestes termos: «ex illis est», «dellos es». Na España de Franco, os que non eran «dos nosos» case non eran xente, eran dos outros, dos españois culpables e ruíns: «ex illis est». Un deles, o escritor Antonio Machado Ruiz (Sevilla, 1875 - Collioure, 1939).

Por esta condición de pertencer ós outros, de ter estado coa España na que cría, era moi difícil, ó finalizar a Guerra, reeditar en España as chamadas Poesías completas súas, cuxa cuarta edición fora impresa no ano 1936, pouco antes da Sublevación. É este un capítulo moi triste na historia da bibliografía española. Hai que chegar a 1941 para que Espasa-Calpe (Madrid) reimprima a cuarta edición desas Completas, anteriores, como xa se dixo, ó 18 de xullo de 1936. Insistimos na cronoloxía editorial para que quede ben claro que na edición de 1941, reimpresión fiel de 1936, non existen poemas «subversivos», nin a grandiosa elexía a Federico García Lorca nin o soneto ó «heroico Líster». No Exército e no mesmo Consello dos Ministros houbo voces, moi poderosas, que se opuxeron á publicación desa quinta edición. Foi preciso que os falanxistas «liberais» de 1940, daquela non exentos de poder (Dionisio Ridruejo, Pedro Laín Entralgo, Antonio Tovar...), montasen unha operación para «rescatar»a Machado, pois, de non facelo, sería un nome exclusivo do exilio español e do antifascismo mundial. A operación protagonizouna, fundamentalmente, Dionisio Ridruejo (1912-1975), falanxista, nesas datas, dun gran prestixio e dono dunha oratoria político-cultural que engaiolaba mesmo os franquistas menos falanxistas. O que necesitaba a editorial Espasa-Calpe para reimprimir as coñecidas Poesías completas era un prologuista das características de Ridruejo; dito doutra maneira, o que se precisaba non era un prólogo, era un aval. Ninguén mellor ca el, que tamén era poeta e fora alumno, no Instituto de Segovia, de don Antonio Machado. Foi o camarada Dionisio Ridruejo, pois, quen escribiu un extenso limiar co título, significativo, de «El poeta rescatado», pois dun «resca- 
te» se trataba. Para Ridruejo, o pobre don Antonio, vello e doente, escribiu ou asinou, en plena guerra, textos e proclamas propios dun «secuestrado moral», que é o que era, nas mans do Frente Popular, aquel home xa con tan poucos folgos. Anos despois, o poeta José Ángel Valente manuscribiría, no seu exemplar desa edición, estas palabras admonitorias (sen data):

\section{El que sienta alguna estima por el autor (¿rescatado?) de este prólogo que no} lo lea nunca.

\section{Sí, este prólogo hay que leerlo con piedad, con melancolía ${ }^{1}$}

Quizais Valente non era, nesa data, moi consciente de que o prólogo fora escrito, en boa parte, para «mitigar» a reacción hostil dos ultras do Réxime. Ese é o verbo, «mitigar», que emprega Ramón Serrano Súñer nunhas datas, 1940, en que tiña moito poder (ministro da Gobernación, Cuñadísimo de Franco...). Trataba de aplacar o xeneral Vigón que lera o famoso prólogo no número 1 da revista Escorial (outubro de 1940), revista minimamente aperturista que, dirixida por Ridruejo e por Laín Entralgo (secretario), tampouco era grata ós sectores non falanxistas do Exército. Ridruejo e os seus decidiron publicar o prólogo antes do volume de Machado para sondear o ambiente. Non sen problemas, publican o volume, co correspondente prólogo, un ano despois, en $1941^{2}$.

Así pois, os españois da década dos Corenta, eu entre eles, tivemos acceso á obra literaria de Antonio Machado porque un grupo de falanxistas cultos e comprensivos desafiaron as actitudes que certos elementos militares —e civísesgrimían nesas datas. Para iso, Dionisio Ridruejo tivo que escribir - e subscribir- moitas «tonterías», palabra esta que o prologuista ten empregado en varias declaracións posteriores exculpatorias. Quizais Valente nos as coñecía.

Nunha España destas características homenaxear a Antonio Machado desde unha óptica esquerdista, por moi cauta e sutil que fose a crítica ó Poder imperante, era imposible ou case imposible. Xa é significativo que as primeiras homenaxes públicas, non exentas de elementos unha miguiña inquietantes para o Réxime, sexan de febreiro de 1959, XX cabodano do escritor. Tamén en Galicia, de xeito moi tímido, 1959 será o ano inaugural dun machadismo minimamente crítico co Poder. Hai anos publiquei unha colectánea co título 23 poetas galegos cantan a don Antonio Machado, volume en que hai datos e textos (tamén posteriores á morte de Franco) reveladores de como foi evolucionando o machadismo en Galicia non só entre 1959 e 1975 senón a partir desta data ${ }^{3}$.

${ }^{1}$ Este exemplar figura na biblioteca da Fundación José Ángel Valente (USC, Facultade de Filoloxía)

2 Sobre esta cuestión v. o meu traballo «Por qué y por quién fue posible leer la poesía de Antonio Machado en España en los primeros años de la Posguerra», Hespérides, UVI (en prensa).

${ }^{3}$ Colección Hipocampo Amigo, Poio-Pontevedra, 2004 (ed. de X. Alonso Montero). 
